University for Business and Technology in Kosovo

UBT Knowledge Center

UBT International Conference

2017 UBT International Conference

Oct 28th, 11:00 AM - 12:30 AM

\title{
Associations of Municipalities in the Republic of Kosovo
}

Ramiz Fazliu

University for Business and Technology, ramiz.fazlliu@ubt-uni.net

Follow this and additional works at: https://knowledgecenter.ubt-uni.net/conference

Part of the Law Commons

\section{Recommended Citation}

Fazliu, Ramiz, "Associations of Municipalities in the Republic of Kosovo" (2017). UBT International Conference. 221.

https://knowledgecenter.ubt-uni.net/conference/2017/all-events/221

This Event is brought to you for free and open access by the Publication and Journals at UBT Knowledge Center. It has been accepted for inclusion in UBT International Conference by an authorized administrator of UBT Knowledge Center. For more information, please contact knowledge.center@ubt-uni.net. 


\title{
Associations of Municipalities in the Republic of Kosovo
}

\author{
Ramiz Fazliu \\ UBT - Higher Education Institution, Prishtinë, Republic of Kosovo \\ ramiz.fazliu@ubt-uni.net
}

\begin{abstract}
The subject of this paper are the forms of cooperation and partnerships of municipalities, respectively the establishment of municipality's associations in the Republic of Kosovo. The Association of Kosovo Municipalities functions currently in Kosovo and it is expected that the Association of Serb-majority Municipalities will soon be established as a result of the Brussels Agreement, reached in the negotiations between the delegations of the republic of Kosovo and Serbia. In addition, it is analyzed and treatedthe legal and constitutional basis for the establishment and functioning of these associations and their position in the legal system of Kosovo. Municipal Associations, their legal status, responsibilities and competencies are sanctioned by the laws that regulate the system of local self-government in the Republic of Kosovo, namely the organization, scope and functioning of municipalities as units of local self-government.
\end{abstract}

Keywords: Association, municipality, local self-government, agreement, partnership

\section{Introduction}

One of the most important attributes of municipalities is the creation of various cooperation for the benefit of the community they have under their administration. Thus the Municipalities in accordance with the European Charter of Local Self-Government and the Law on Local SelfGovernment, they have the right to cooperate and to establish partnerships with other municipalities of the Republic of Kosovo, within the scope of their competencies.Municipal partnership activities are funded by municipal budgets of participating municipalities and can take all necessary measures to exercise and implement functional cooperation through the establishment of a decision-making body composed by appointed representatives of participating assemblies. The partnership decision is subject to estimate the legality in accordance with the law on local self-government.80 Intermunicipal Cooperation and Municipal Partnerships between the Municipalities of the Republic of Kosovo, based on the proposal of the comprehensive plan of the Ahtisaari Package on the status, the Constitution of Kosovo and the Law on Local Self-Government, still remains a challenge for the democratic institutions of the Republic of Kosovo on its reform processof the local government, while in practice are not implemented the functional priorities of services for the citizens without being influenced by the politics and political manipulation of the Serb minority in the Republic of Kosovo.

${ }^{80}$ See Article 29 of Law no. 03 / L-040 on Local Self-Government; 


\section{Association of Kosovo Municipalities}

The Law on Local Self-Government in its Article 31 foresees the range of other co-operations that municipalities may have. Therefore, in this article it is stipulated that "for the protection and promotion of their common interests, municipalities form and participate in associations that function within the constitution and law. The associations of municipalities in the Republic of Kosovo are established on the basis of the Law on Local Self-Government81 (their establishment isforeseen with the Ahtisaari Comprehensive Plan for Serb-majority municipalities)82and the European Charter for Local Self-Government83. The Association of Kosovo Municipalities is a non-profit organization, a legal entity established by the municipalities of the Republic of Kosovo and represents their general interests. The activities of the association are based on the principles of volunteering of its members, the principles of democracy and the principles of power decentralization. Members of the Association are the municipal authorities of the Republic of Kosovo. Municipalities can join the representative associations of the local self-government bodies of the Republic of Kosovo after the decision taken by the respective Municipal Assembly. Such associations can provide their members with a number of services, including buildingcapacity, technical assistance, municipal competency research and policy recommendations.

The Association has the freedom of action, the right of policy initiatives and recommendations as an intermediate voice between the local government and the central government in order to improve the quality of services, increase transparency and public accountability of institutions. Considering the need for inter-municipal cooperation and the affirmation of Kosovo's local policy in international institutions, the Association of Kosovo Municipalities was established on 31st July 2001. Since 22nd of March2002, Kosovo's local government has received observer status at the Local Government Congress Regional Council (CLRE) in Strasbourg. The observer status for the local authorities of the Republic of Kosovo is expected to be transformed with the full rights of the member, after Kosovo's accession to the Council of Europe, the signing and ratification of the European Charter of Local Self-Government. The Association of Municipalities of the Republic of Kosovo is committed to implement the rules of the European Charter on Local Self-Government. The Association organizes and coordinates the activities of members in the area of investment, economic development of municipalities, improvement of the legal base and rule of law, improving conditions in education, science, health support, social issues, and improvement of services for citizens, for relationship with associationsoutside the country and international organizations ${ }^{84}$. The activity of Association of Municipalitie is regulated through the Statute of the Association, which foresees the fulfillment of its objectives and tasks ${ }^{85}$. The Association of Municipalities has its

\footnotetext{
${ }^{81}$ See Article 31 of Law no. 03 / L-040 on Local Self-Government;

${ }^{82}$ See Article 9 of the Ahtisaari's Comprehensive Plan, Annex III;

${ }^{83}$ See Article 10 of the European Charter of Local Self-Government..

${ }^{84}$ See Article 2 paragraph 1 of the Statute of the Association of Kosovo Municipalities;

${ }^{85}$ See Article 3 of the Statute of the Association of Kosovo Municipalities, which determinates that the tasks are: Initiates, organizes and promotes cooperation between municipal authorities of the Republic of Kosovo, proposes the solution of general problems of municipal authorities, issues methodological materials which are given to municipal authorities; Provides opinions, suggestions and remarks on draft laws and sub-legal acts related to municipal governance; Provides organizational and legal assistance to municipal authorities; Represents the general professional interests of civil authorities and services by the municipal authorities; Represents the interests of its members in front of foreign authorities and international organizations and assists
} 
governing bodies, which are: the Assembly, the Council, the Board and the Chairman of the Association. The statute also foresees the extinction of the work and activity of the association. Therefore, the association ceases its activity if the Assembly of the Association decides to cease with $2 / 3$ (two thirds) of all its members or by a decision of the state body (the body that has registered the Association) if more than half of the members abandon membership in association.

Association / Community of Serb-majority Municipalities

As a result of the technical talks initially, and later the same became political talks and negotiations in Brussels, between the delegations of the Republic of Kosovo and the Republic of Serbia, and with the mediation of the representative of the European Union, the reachedAgreement was recognized by Brussels, which was signed on 19 April 2013. The agreement in its entirety has 15 points and 8 (eight) pointsof them that reflect in the field of municipal responsibilities - Association of Serb majority municipalities which are as follows:

It will be an Association / Community of Serb-majority municipalities in Kosovo. Membership in it will be open to other municipalities mentioned in the agreement.

The Association / Community shall be established by the statute. Its dissemination will only take place through a decision of the participating parties. Legal guarantees will be provided through the applicable law and constitutional law, including $2 / 3$ of the majority of the decision-making body.

The association / community structures will be established on the same basis as the existing status of the Association of Kosovo Municipalities, such as the Chairman, the Deputy Chairman, the Assembly, the Council.

A compliance with the competencies given by the European Charter on Local Self-Government and the Kosovo Law, the participating municipalities will have the right to cooperate in exercising of their collective powers through the Association / Community. The Association / Community will have full access to the areas of economic development, education, health, urbanism, and rural planning.

The Association / Community will exercise additional responsibilities, depending on how those are delegated by the central authorities.

The Association / Community will have a presentation role in the central authorities and, for this purpose, will have a seat in the Community Consultative Council. Accordingly isforeseen a monitoring function.

There will be a Regional Police Commander for the four Serb-majority municipalities (North Mitrovica, Zvecan, Zubin Potok and Leposavic). The commander of this region will be a Kosovo Serb, nominated by the Ministry of Interior from a list to beprovided by the four mayors of the abovementioned municipalities

Municipal elections in northern municipalities will be organized in 2013, with the assistance of OSCE, in accordance with Kosovo law and international standards. ${ }^{86}$

The establishment of the Association of Municipalities with Serb-majority Municipalities is supported by the following legal acts: the Law on Local Self-Government ${ }^{87}$, the Ahtisaari

municipal authorities to cooperate with the external partners; Organizes and coordinates professional trainings for municipal authorities; Organizes and coordinates the circulation of information for its own members and publishes its own publications; Opens representative offices, creates capacity building mechanisms for municipal authorities; Performs other services for its own members.

${ }^{86}$ See points of the Brussels Agreement relating to the Association of Serb-majority municipalities.

${ }^{87}$ See Article 31 of Law no. 03 / L-040 on Local Self-Government; 
Comprehensive Plan for Serb-majority Municipalities ${ }^{88}$, the European Charter for Local SelfGovernment ${ }^{89}$, the First Agreement of Brussels (19 April 2013) ${ }^{90}$, the Decree of the Government of Kosovo $^{91}$ and the Statute ${ }^{92}$.

This agreement has initiated a lot of criticism and debate within intellectual and social circles. The debate and criticism mainly deal with the dilemmas that with this agreement is overtaken the Ahtisaari plan, or with this agreement we have Ahtisari plus. According to the agreement ratified by the Assembly of Kosovo, we see that the Ahtisaari Plan has not been overtaken in regard to the principles for the establishment of Association / Community for Serb majority municipalities in the Republic of Kosovo. All points contained in the agreement and the solutions reached on this issue are within the legal and constitutional system of Kosovo and similar to the principles, founding act, objectives, competences and organizational structure of the current Association of Kosovo Municipalities. Therefore, it is more closely foreseen in the point 2 of the Agreement that: "The Association / Community shall be established by the statute. Its dissemination will only happen through a decision of the participating parties. Legal guarantees will be provided through the applicable law and the constitutional law "93...

But it is worth pointing out that what is in objection to the Ahtisaari Plan and considered to have been exceeded by Ahtisaari's plan with this agreement it has to do with the status of the city of Mitrovica. Ahtisaari's plan foresees the two municipalities to function within a board, preserving the character of a city, and the Brussels Agreement finally recognizes the reality of the city divided into two municipalities; South Mitrovica with Albanian majority and North Mitrovica with Serb majority and with two separate administrations. Thus, it is not foreseen the establishment of a joint board for the two administrations of the same city, the Brusselsagreement has completely canceled the 13th point of the Ahtisaari Plan.

After this agreement, which, after ratification by the Kosovo Assembly, has become part of Kosovo's internal legal system. With this, the institutions of the Republic of Kosovo are obliged realize the same, establishing the Association / Municipalities of Serb-majority municipalities.

As time passess, talks and negotiations between the parties continued for other parts of the First Agreement, so the Kosovo side under the constant pressure of the Kosovo Serb community and its representatives, in particular the Belgrade delegation, to implement as soon as possible the First Agreement, on August 25, 2015, accepted and approximated another document named: Association / Association of Serb-majority Municipalities in Kosovo-General Principles / Main Elements. This act does not fall into the category of legal acts or international agreement and therefore does not undergo either the Ratification procedure, as the main basis derived from the First Agreement of Brussels. The aproved Act as the Principles of the Association can be categorized as an interim legal act, which derives from another legal act in this case International Agreement, adds new elements outside the framework of the First Agreement, foreseeing that in the process of creation and the legal entity itself (Association) and precedes the founding act (decree of the Government of Kosovo for establishment under Article 2 of the Association Principles), serving as conditionality of the founding act.

${ }^{88}$ See Article 9 of the Comprehensive Ahtisaari Plan, Annex III;

${ }^{89}$ See Article 10 of the European Charter of Local Self-Government;

${ }^{90}$ See point 1 of the First Brussels Agreement, ratified by the Kosovo Assembly on 23 June 2013;

${ }^{91}$ The Government Decree on the Establishment of the Association shall be subject to prior assessment by the Constitutional Court

${ }^{92}$ The Statute shall be approved by the Founding Assembly, which shall be in accordance with the Law and the Constitution;

${ }^{93}$ See point 2 of the Brussels Agreement of 19 April 2013. 
Therefore, making a comparison between the First Agreement and the General Principles (subsequent act), there are substantial differences both in terms of form and substance between these acts:

From the title itself of General Principles, as the category of ethnicity is emphasized, can not be in the common interest of the municipalities. This is because "ethnicity" does not fall within the sphere of competence or municipal function on the basis of which municipalities may require intermunicipal and cross-border cooperation under Article 124 paragraph 4 of the Constitution and Article 10, paragraph 1 of the European Charter for Local Self-Government. Therefore, the use of the phrase "majority Serb municipality" in the title and in the text of the General Principles should be declared incompatible with Article 3, paragraph 1. And with Article 124 paragraph 4 of the Constitution as well as with Article 10, paragraph 1. The European Charter on Local SelfGovernment.

a) Contrary to General Principles, the Agreement does not definethe Association / Communityas a "legalentity" of the particular character,

b) Theagreement does not foresee the establishment of the Association by a decree of the Government,

Theagreement does not specify the budget, the administration (employees civil status) and the competencies of the Association, which according to the Principles are foreseen to be executive. Instead, the Agreement provides that the competencies of the Association shall be exercised in accordance with the European Charter on Local Self-Government and that the structures of the Association shall be established on the same basis as the existing Statute of the Association of Kosovo Municipalities.

Taking these facts into account, there is a need for constitutional interpretation and review of the Compliance Principles of the Association with the legal and constitutional system of Kosovo. For this purpose, the President of Kosovo, on the basis of the authorizations given by the Constitution, respectively Article 112.1, asks the Constitutional Court to assess the constitutionality and compliance of the Principles with the relevant constitutional provisions.

The Constitutional Court, after receiving the Referral, reviewed and evaluated compliance with the constitutional and legal provisions of the General Principles of the Act of 25 August 2015, concluded and decided that:

The First Agreement, ratified on 27 June 2013, provides the establishment of an Association / Community of Serb-majority municipalities in Kosovo. The establishment of this Association / Community will be done with the Statute. Regarding the organizational structure, functions and rights, scope and other powers delegated by the central authorities, the Statute of the Association / Community should be the same as the Statute of the existing Association of Kosovo Municipalities. These principles should be in accordance with the principles of the European Charter on Local SelfGovernment and Kosovo's internal legal system.

Principles elaborated in "Association / Association of Serb-majority Municipalities in Kosovo General Principles / Principal Elements" are not entirely in accordance with the spirit of the Constitution, Article 3 (Equality before the Law), paragraph 1.me Chapter II (Fundamental Rights and Freedom) and Chapter III (Rights of Communities and their Members) of the Constitution of the Republic of Kosovo.

The legal act of the Government of the Republic of Kosovo - the Decree and the Statute implementing the Principles to be in compliance with the spirit of the Constitution, Article 3 (Equality before the Law), paragraph 1, Chapter II (Fundamental Rights and Freedoms) and Chapter III (Rights of Communities and their Members) of the Constitution of the Republic of Kosovo must meet constitutional standards and must comply with Articles 3, 7, 12 and Chapter II of Fundamental Rights and Freedom, with articles 21 and 44, Chapter III (Rightsof Communities and their 
members) with articles 57,59,60,61 and 62, as well as articles 79,81,93,101,113,123,124 and 137 of the Constitution of the Republic of Kosovo.

A provisional measure is imposed on 10 November 2015, which ends with the entry of this Judgment into force.

It is Declared that the Judgment, shall enter into force immediately. ${ }^{94}$

\section{Conclusion}

As it was said above, the Association of Municipalities of Serb majority municipalities will be established by the Republic of Kosovo ratifying the Brussels Agreement, this is why it became an integral part of the Kosovo legal system, and as an international subject it has an obligation to implement all the commitments that emerge from these international instruments. However, there must be always in consideration that this Association, the bodies, the structure, the competences and the functions must comply with the law and the Constitution of Kosovo.

\section{Literature:}

6. Constitution of the Republic of Kosovo, Pristina 2008

7. Law no. 03 / L-040 on Local Self-Government in the Republic of Kosovo; 2008

8. Ahtisaari's Comprehensive Plan, Annex III; 2007

9. European Charter for Local Self-Government, Council of Europe 1985.

10. Brussels Agreement, 19 April 2013

11. Statute of the Association of Kosovo Municipalities. 2001

12. The Document "Association / Association of Serb-majority Municipalities in KosovoGeneral

13. Principles / Main Elements" 15 August 2015

14. Judgment of the Constitutional Court of the Republic of Kosovo, issued on 21 December

15. 2015, promulgated on December 23, 2015, Ref. No. AGJ 877/15

${ }^{94}$ See the Judgment of the Constitutional Court of the Republic of Kosovo, issued on 21 December 2015, and Announced on December 23, 2015, Ref. No. AGJ 877/15 